\title{
Joint overview of the Rhédey Castle and Park in Sângeorgiu de Pădure based on maps resulting from military measurements
}

\author{
Lóránt KOVÁCS \\ Sapientia University, Faculty of Technical and Human Sciences, \\ Department of Horticulture, Târgu-Mureș, Corunca 1/C \\ kovacs_lorant@yahoo.com
}

Manuscript received Sept. 30, 2016; revised Oct. 29, 2016; Accepted Nov.10, 2016

\begin{abstract}
Sângeorgiu de Pădure (in Hungarian: Erdőszentgyörgy) is situated 37 km south-east of Târgu-Mureș, in the Târnava Mică valley, at an altitude of $340 \mathrm{~m}$ above see level. It was first mentioned in 1333 as 'Sancto Georgio's' in contemporary documents. In the middle of the $16^{\text {th }}$ century, the most important holder was the Göncruszkai Kornis family [1]. Councillor John Rhédey became the owner in 1627, when the settlement's name was already the actual name 'Sangherghiu de Padure'. On January 16, 1629, it was donated by Gábor Bethlen to John Rhédey and his wife, Margit Kornis. According to tradition, a reinforced abbey, church, and monastery were placed where the actual castle and its garden were settled. In 1569, the new building named Kornis Castle was built on the ruins of the former monastery. Here was born on September 1, 1812 Klaudia Rhédey, her later name being Countess of Hohenstein, known as the founder of the well-known British Windsor house dynasty.
\end{abstract}

Keywords: Rhédey Castle, Sancto Georgio, Rhédey Klaudia, Kornis family

\section{The history of the castle}

Using materials from the former Castle of Kornis, the actual castle was built up by masters from Târgu-Mureş in the second half of the $19^{\text {th }}$ century - more precisely its first version of today's Rhédey Castle. Constructions started on Rhédey (V.) Sigismund's (1727-1758) and his wife's, Catherine's, order. After Sigismund's death, the owners became his son Ferenc, and then (1756-1772), after his death, the castle passed to László. The building suffered further modifications during László Rhédey's and his wife's ownership, in the period of 1807-1809 [2]. 
Countess Claudine Rhédey de Kis-Rhéde, daughter of Count László Rhédey IX, was the wife of Duke Alexander of Württemberg, but she died tragically in Gratz, Austria, in 1841. Their child, Prince Francis of Tech was educated in England and married an English princess. Their daughter, Princess Victoria Mary, wife of King George V, erected a marble slab to the memory of her grandmother, Claudine, in the Reformed Church in Sângeorgiu de Pădure [3]. The plaque reads the following text in Hungarian and English:

"To the memory of Countess Claudia Rhédey, Countess of Hohenstein, wife of Duke Alexander of Württemberg, his Royal Highness. Erected by her granddaughter: Mary, Princess of Wales."

After World War I, the owner of the Rhédey Castle was the Schuller business house and from 1935 onwards several governmental agencies operated in the building. The castle garden can be thoroughly studied with the help of the military surveys maps. According to the I. Military Map, the castle around the park as well as the garden can be well distinguished. To the north of the castle, on a hillside, a crypt can also be seen. The survey shows approximately ninety images on the northern side of Târnava Valley (Figure 1).

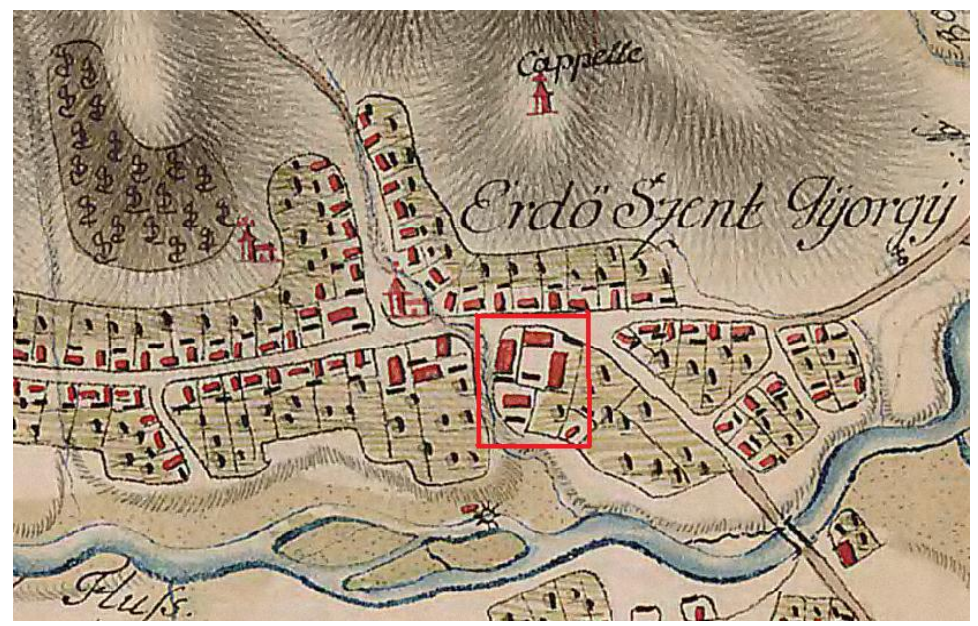

Figure 1. The Rhédey Castle on the I. Military Survey Map

The II. and III. Military Survey Maps are very similar to each other. Already listed in the appendix, the castle park is well distinguishable on the II. Military survey map. Around the castle, an amazing French garden can be seen with walkways and diagonally arranged, trimmed plant compositions. In the middle of the garden, a fountain was built and other characteristic structures of French gardens as greenhouses and small forest parks were also constructed. The best 
images of the historic park come from a $19^{\text {th }}$-century engraving that shows the former French garden as it once was (Figure 2).

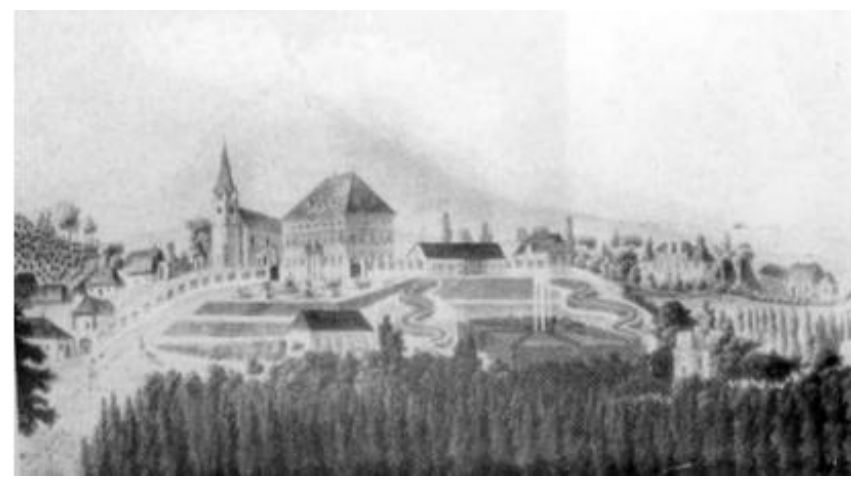

Figure 2. Engraving of the Rhédey Castle in Sângeorgiu de Pădure at the beginning of the $19^{\text {th }}$ century - Biró J., 1943, LVI. plate

\section{The actual stage of the castle and its park}

The Rhédey Castle's actual structure reveals the late Baroque style and reminds more of an urban or city castle than of a rural bunk. The historic building was finished in its actual form in the years 1807-1809, during the reconstruction works (Figure 3) [2].

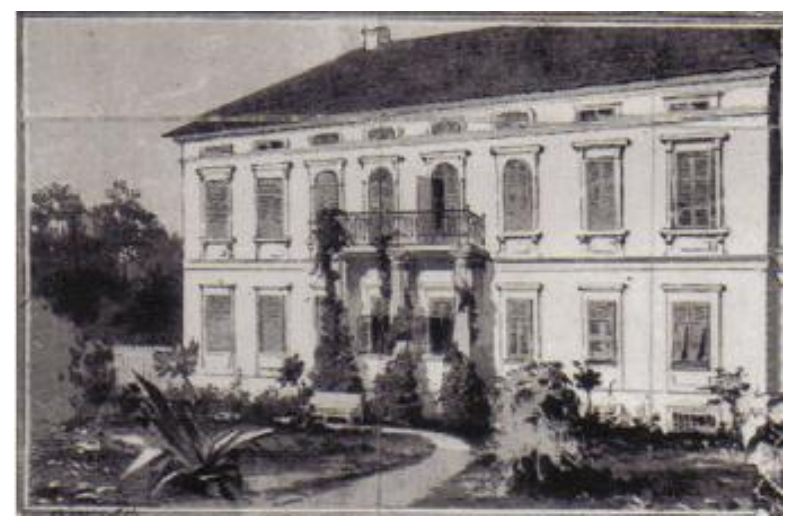

Figure 3. The Rhédey Castle in Sângeorgiu de Pădure - original drawing of Károly Cserna - keptar.oszk.hu/060218 
On the ground-floor rooms, the floors are knuckled and ornately painted. The ceiling of the large salon on the first floor is higher than any other rooms; however, a wood-beamed ceiling was created inside the salon during the communist regime. The original, ornate paintings remained intact in this way. The dominant elements on the eastern and western façades are the balconies [4]. The historic building was the place of the local elementary school between 1948 and 2010. In 2011, renovation works were carried out funded by the Ministry of Culture and National Heritage: the castle doors, windows, roof linings, and the building's pillars were rebuilt to their former and original state [5]. Today, the castle is planned to be used for the purposes of tourism and culture and to give place to exhibitions, restaurants, and wineries (Figure 4).

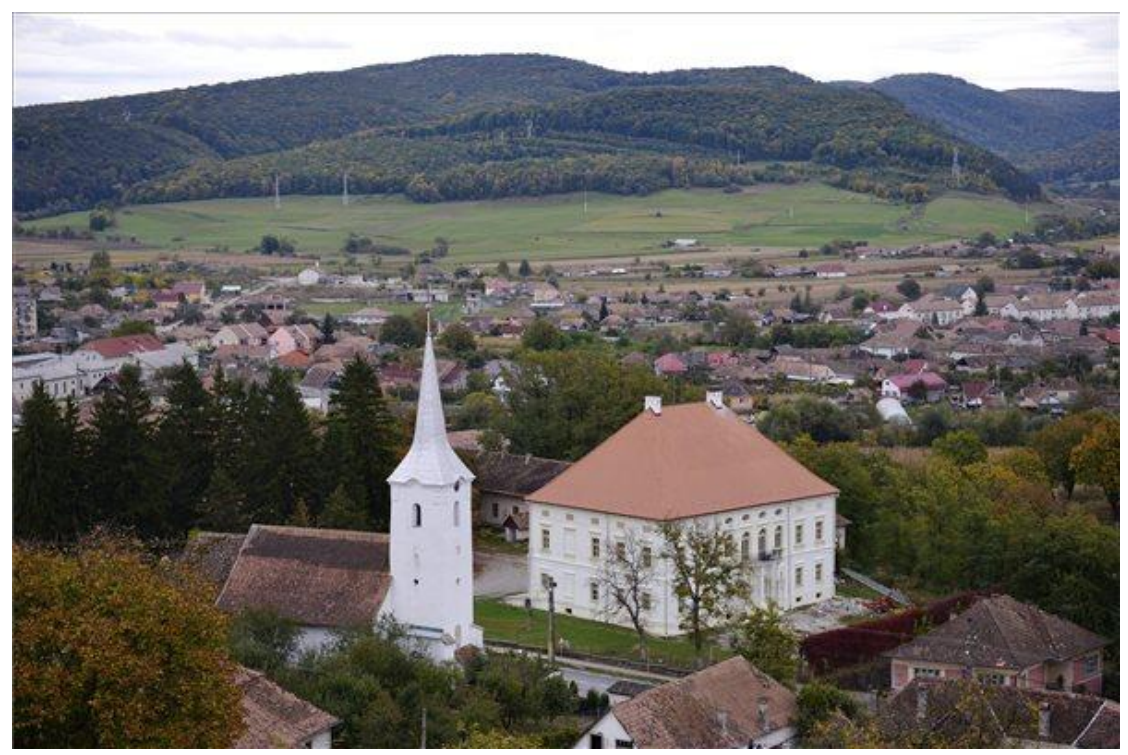

Figure 4. The Rhédey Castle in Sângeorgiu de Pădure - MTI Photo: László Beliczay

On the basis of the surveys, the original castle park was almost destroyed and used for agricultural purposes. Just a small garden place remains in front of the Castle, incorporating a monument of World War II. In spite of its historical importance, the former park and garden survive only in historic documents, maps, drawings, and photographs (Figure 5). 


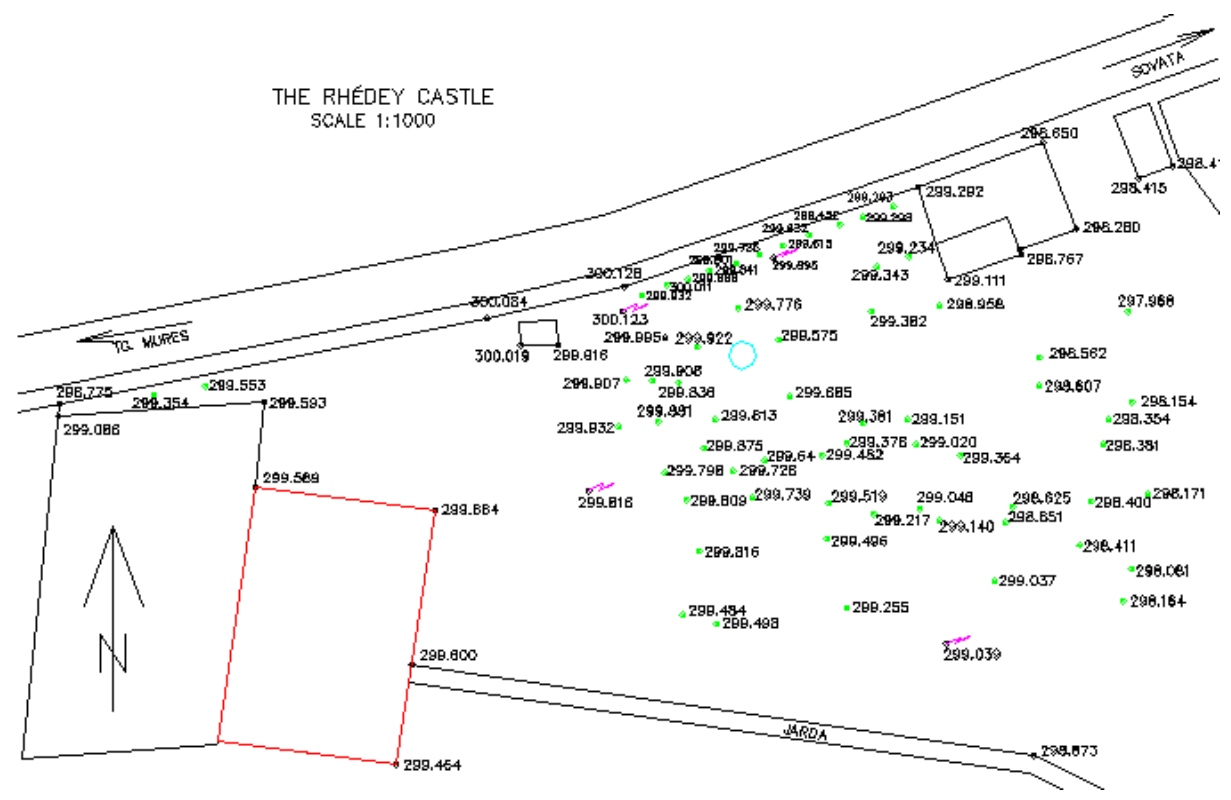

Figure 5. Geodetic survey of the Rhédey Castle

\section{References}

[1] Vofkori, László (1998), Székelyföld útikönyve 1. Budapest.

[2] Keresztes, Gyula (1995), Maros megyei kastélyok és udvarházak. Marosvásárhely.

[3] B. Nagy, Margit (1973), Várak, kastélyok, udvarházak. Bukarest.

[4] Biró, József (2002), Erdélyi kastélyok. Budapest.

[5] Erdőszentgyörgyi Figyelő, 2004, április. 